UDK: $342.724 / .725(=135.1)(497.11) ; 81^{\prime 2} 26: 316.7(497.11)$

\title{
- OČUVANJE MANJINSKIH JEZIKA I JEZIČKA POLITIKA NA PRIMERU VLAŠKE MANJINSKE ZAJEDNICE U SRBIJI
}

\author{
JASNA POPOVIĆ ${ }^{1}$ \\ Student doktorskih studija Filološkog fakulteta \\ Univerziteta u Beogradu
}

U ovom radu istražuju se mogućnosti očuvanja manjinskih jezika koji su veoma ugroženi u državama sa dominantnom monolingvalnom ideologijom. Jezička ljudska prava i jezička obrazovna politika dobijaju sve veći značaj na međunarodnoj političkoj sceni budući da su u ovakvim okruženjima neophodan preduslov za očuvanje ugroženih jezika i jezičkog diverziteta. U radu je dat osvrt na etničke manjine u Srbiji i njihov pravni položaj, i tvrdi se da je država Srbija, na osnovu niza zakona kojima garantuje širok krug prava nacionalnim manjinama, bar deklarativno orijentisana ka modelu jezičke raznovrsnosti i očuvanju manjinskih jezika. Rad se dalje fokusira na položaj i jezička prava vlaške manjinske zajednice u Srbiji. Vlaški jezik nije standardizovan niti prihvaćen od strane Nacionalnog saveta Vlaha za zvanični jezik vlaške zajednice pa samim tim ne može biti obuhvaćen državnom obrazovnom politikom. U radu se zastupa stav da država treba da pronađe mehanizme koji bi pomogli očuvanju i razvoju etničke, kulturne i jezičke posebnosti Vlaha i više radi na podizanju svesti 0 značaju multikulturalnosti i višejezičnosti.

Ključne reči: jezička raznovrsnost, imigranti, jezička politika, Srbija, vlaška manjinska zajednica.

\section{UVOD}

Procesi industrijalizacije i globalizacije se negativno odražavaju na jezičku raznovrsnost i manjinske jezike i kulture. Statistika pokazuje da od oko 6.700 jezika koliko ih danas ima na svetu, samo 600 jezika ima više od 10.000 govornika, što je minimalni broj da bi opstanak jezika bio siguran. U stvari, $90 \%$ svetskog stanovništva govori samo 100 jezika, ostalih 6.600 jezika upotrebljavaju male grupe govornika i može se reći da njihov broj konstantno opada (Hinton 2003: 44). Pored ovog, gubitak

1 Kontakt podaci (Email): jasnapop@yahoo.com 
jezika simbolizuje i krizu biodiverziteta, pošto urođenički jezici sadrže mnoštvo ekoloških informacija koje će biti izgubljene zajedno sa jezikom. Kako bi se stalo na put izumiranju i zameni jezika, 70-ih i 80-ih godina nastao je pokret za održanje jezika koji je nastojao da sačuva status quo za manjinske jezike. Međutim, od 1990-ih godina sve veći broj naučnika i istraživača obraća pažnju na gorući problem izumiranja jezika i iz toga se rađa pokret revitalizacije jezika, čiji cilj nije puko preživljavanje nekog manjinskog jezika koji je već u procesu zamene, već vraćanje komunikativnih funkcija u različitim domenima i medijumima upotrebe. Međutim, da bi se to postiglo potrebno je obučiti nove govornike, odnosno pomoći ljudima da nauče jezik u situacijama gde uobičajeni transgeneracijski prenos više ne postoji (ibid.,45).

\section{POZITIVAN BILINGVIZAM KAO NAČIN OČUVANJA IMIGRANTSKIH JEZIKA}

Mnoge zapadne zemlje imaju veliki broj imigranatskih grupa. Za razliku od drugih manjinskih zajednica koje vekovima žive na nekoj teritoriji, imigrantske zajednice ne traže teritorijalno samoupravljanje niti status zvaničnog jezika. Njihove nove zemlje pretpostavljaju da će oni naučiti njihov jezik, budući da je to uslov za dobijanje državljanstva u većini zapadnih zemalja. Imigranti obično prenose svoj maternji jezik deci, i koriste ga u svom domu ili crkvi, ali ga njihova deca retko prenose sledećoj generaciji pa dolazi do zamene jezika već u trećoj generaciji. Ovaj šablon zamene jezika je bio toliko uobičajen da su ga mnogi smatrali neizbežnim. Međutim, nekoliko trendova uzdrmalo je ovaj istorijski obrazac: porast imigrantskog "transnacionalizma", odnosno tendencije imigranata da održavaju veze sa svojom matičnom zemljom i kulturom, kao i porast ideologije multikulturalizma, odnosno ideje da imigranti ne treba da napuste svoj etnički identitet da bi se integrisali, kao što su iziskivali stari modeli asimilacije, već da treba da ga vidljivo izražavaju u javnoj sferi što državne institucije treba da omoguće (Kymlicka/Patten 2003: 6). Ovi trendovi uslovili su potrebu za kreiranjem državnih jezičkih politika koje prepoznaju multietničnost i postojeće jezičko šarenilo koje je karakteristika najvećeg broja modernih država.

Sjedinjene Američke Države predstavljaju dobar primer države koja, iako u stvarnosti izrazito višejezična zahvaljujući desetinama jezika koje su unete imigracijom iz svih delova sveta, održava dominantnu monolingvalnu ideologiju. Iako statistika pokazuje da danas preko 30 miliona stanovnika ove zemlje ne govori engleski kao maternji jezik, institucionalna podrška monolingvalizmu je već decenijama izuzetno jaka, toliko da je bilo nekoliko neuspelih pokušaja da se engleski proglasi jedinim nacionalnim jezikom države. Mnogi smatraju da je on već toliko dominantan i prestižan u odnosu na ostale urođeničke i imigrantske jezike da dodeljivanje statusa nacionalnog jezika nije ni neophodno. Međutim, u cilju jačanja američkog nacionalnog identiteta u SAD-u, nastali su pokreti poput English-Only Movement ili U.S. English koji propagiraju isključivu upotrebu engleskog jezika na državnom nivou. Ovi pokreti se zalažu, između ostalog, za stimulisanje zamene jezika, za davanje veće javne podrške jezičkim obukama i za reformu koja vodi ka ukidanju programa tranzicionog bilingvalnog obrazovanja za decu imigranata. Pristalice ovih 
pokreta smatraju da upotreba drugih jezika osim engleskog nije potrebna, da je u suprotnosti sa duhom američke nacije, i da ukoliko njihovi govornici žele stvarno da se integrišu u američko društvo i prihvate američke vrednosti moraju preći iz jednog monolingvalizma u drugi. Engleski zapravo znači ne-španski: španska jezička zajednica, koja bi po svojoj snazi i brojnosti trebalo da ima glavnu reč po pitanju učenja stranih jezika zapravo nema nikakav uticaj na kreiranje jezičke politike u Americi koja je anglofona (Edwards 2001: 118).

Sjedinjene Američke Države nemaju eksplicitnu nacionalnu jezičku politiku, i mada ne ignorišu u potpunosti pitanje jezičkog obrazovanja jezičkih manjina, one ne pokazuju jaku nacionalnu posvećenost očuvanju multilingvalizma ili zaštiti jezičkih manjina (Harper 2011: 518). Tokom proteklih decenija u SAD-u je nastao znatan broj zakona koji se tiče jezičkog obrazovanja, i mada ovi zakoni prepoznaju interese govornika drugih jezika, sve je uočljiviji trend insistiranja na usvajanju engleskog i asimilaciji nego na multilingvalnosti. Plurilingvalnost se doživljava kao pretnja nacionalnom identitetu koju je potrebno iskoreniti. Vrhovni sudovi, Kongres i savezne države donosile su u proteklom veku niz odluka u korist jezičke diskriminacije koje ukazuju da je jezički diverzitet zapravo marginalizovan u SAD (ibid.,526). Istraživanja su pokazala da gotovo sve imigrantske grupe zamene jezik već u trećoj generaciji, a ignorisanjem ove činjenice, jezičke obrazovne politike koje se sprovode u državnim školama u SAD tome samo doprinose. Važan izuzetak od ovog procesa zamene jezika je samo španski koji raste velikom brzinom (Bugarski 1996: 77). Pretpostavlja se da danas živi oko 30 miliona govornika španskog u Americi što ih čini najvećom manjinskom zajednicom. Za razliku od drugih imigrantskih grupa koje su već u drugoj generaciji gubile maternji jezik, do ove zamene nije došlo u španskoj zajednici uprkos jakim pritiscima države. U ovakvom neprijateljskom okruženju gde su podsticaji za jezičkom asimilacijom veoma jaki, uslov za očuvanje španskog u SAD-u je lingvistička segregacija, odnosno stvaranje autonomnih organa u španskoj govornoj zajednici u cilju očuvanja jezika (Eriksen 1992: 324). Trenutno, govornici španskog jezika u Americi imaju veliki broj novina, časopisa, TV i radio stanica na španskom, kao i ograničen pristup osnovnom obrazovanju na španskom koji finansira država. To su sve preduslovi koji omogućavaju španskoj zajednici da se razvija i ojača u toj meri da može da bude konkurentna maternjim govornicima engleskog, i to na svom, španskom jeziku. Međutim, ova jezička segregacija je moguća isključivo zbog brojnosti španske zajednice u Americi, dok drugi imigrantski i urođenički jezici ne mogu dugoročno opstati bez jasne i sistematske jezičke politike na državnom nivou koja će brinuti o njihovom očuvanju.

Slični anti-imigrantski stavovi i nastojanja za njihovom brzom asimilacijom postoje i u Zapadnoj Evropi, gde je kao razlog za teškoće u integraciji imigranata istican nedostatak njihove volje da nauče državne jezike. Istraživanja pokazuju da imigrantska deca u Zapadnoj Evropi ostvaruju lošiji uspeh u školi u odnosu na njihove vršnjake iz većinske jezičke zajednice. U zvaničnim državnim publikacijama se za loše rezultate u obrazovanju ne optužuje školski sistem, već se okrivljuju njihovi roditelji koji navodno ne razumeju značaj obrazovanja i imaju staromodne vrednosti koje sprečavaju njihovu decu da uče i ostvaruju uspehe u školi (Skutnabb-Kangas/Phillipson 1996: 299). Pored roditelja, mnogi političari i istraživači iznose stav da zbog samih urođenih osobina 
imigranata oni nisu u stanju da ostvare značajne rezultate u školama. Međutim, istraživanja ukazuju da na rezultate imigrantske dece u školama zapravo utiče njihova nedovoljna kompetencija na jeziku instrukcije (Christensen/Stanat 2007: 2). Veliki broj imigranata kod kuće govori jezikom koji se razlikuje od jezika instrukcije u školama i drugim obrazovnim institucijama. To praktično znači da jedan petnaestogodišnjak koji ne govori jezikom instrukcije kod kuće zaostaje godinu dana za svojim vršnjakom kome je maternji jezik ujedno i jezik instrukcije. Dakle, neophodno je da deca imigranata steknu kompetencije na jeziku instrukcije kako bi imala podjednake šanse u akademskom svetu kao i njihovi vršnjaci; najčešće se s tim u vezi ističu intenzivni monolingvalni programi koji pomažu učenicima da usvoje jezik instrukcije tako što su mu konstantno izloženi. Međutim, države treba da ponude i bilingvalne programe kako bi negovale multilingvalnost kao resurs. Jezička politika sa orijentacijom „jezik kao resurs" podstiče vitalnost i očuvanje ugroženih imigrantskih i urođeničkih jezika (Hornberger 1998: 452). Poznato je da školski sistem ne može očuvati ugrožene jezike ukoliko nema generacijskog prenosa, ali pojedini naučnici ističu da su ključni elementi kod obrazovanja imigrantskih i drugih manjinskih zajednica upravo bilingvalna i bikulturalna raznovrsnost i bilingvalno obrazovanje. Važno je dati izbor manjinama da same odlučuju o tome koje jezike žele da unapređuju i u koje svrhe.

Imigranti žele da očuvaju svoj jezik pred socijalnim, političkim i ekonomskim pritiscima da se asimiluju i prihvate jezik i kulturu njihove nove zemlje. Oni zapravo žele da im se omogući da nauče i koriste novi jezik, ali i da sačuvaju i koriste i svoj maternji, „stari“ jezik u njihovoj novoj zemlji. Ova želja za pozitivnim bilingvizmom je prisutna kod imigrantskih zajednica širom sveta, ali je uočljivo nastojanje njihovih novih država da im nametnu izbor između ova dva jezika ili da potpuno ignorišu obe želje. Iz ovog razloga, jezička ljudska prava i jezička obrazovna politika dobijaju sve veći značaj na međunarodnoj političkoj sceni. Oni predstavljaju mehanizam za održanje i razvoj manjinskih jezika koji države treba da primene ukoliko žele da se jezički i kulturni divezitet sačuva. Filipović (2009: 58) ističe da se jezička ljudska prava formulišu u skladu sa deklaracijama o opštim ljudskim pravima i pozivaju na proaktivno političko i moralno delanje, promociju i prihvatanje relevantnih političkih i društveno-kulturnih sporazuma na nivou država i međunarodnih institucija. Na dve konferencije koje su organizovane pod pokroviteljstvom UNESCO-a zahtevano je usvajanje Univerzalne deklaracije o jezičkim pravima koja bi osigurala upotrebu manjinskog jezika u službenim situacijama i učenje i na maternjem i na zvaničnom jeziku u zemlji boravka. Deklaracija generalno podržava pravo pojedinaca na obrazovanje na maternjem jeziku i na određeni stepen kontrole nad obrazovnim procesom u koji su uključena imigrantska deca (Hornberger 1998: 451). Iako postoji veliki broj povelja, deklaracija i konvencija koji povezuje ljudska prava sa jezičkim pravima regionalnih ili nacionalnih manjina, u mnogim nacionalnim državama se manjinama i dalje uskraćuje pravo na obrazovanje na njihovom maternjem jeziku. Generalno gledano, postoje napori za kodifikovanje prava manjinskih jezika ali oni još nisu dali rezultate koji bi se ogledali u institucionalnoj podršci manjinama da održavaju i razvijaju svoje jezike, naročito u obrazovnom sistemu (Phillipson/Skutnabb-Kangas 1997: 43). 


\section{ETNIČKA STRUKTURA U SRBIJI I PRAVNI POLOŽAJ ETNIČKIH MANJINA}

Mnoge države sveta, od kojih neke važe za uzore demokratije, negiraju ili prećutkuju da na njihovoj teritoriji postoje razne, ponekad i vrlo brojne manjine, pa je bespredmetno diskutovati o jezičkim i drugim pravima tih zajednica kada one zvanično - ne postoje (Krivokapić 1996: 158). Srbija ne samo da priznaje činjenicu njihovog postojanja, već im svojim Ustavom i nizom zakona garantuje širok krug prava.

Naime, Srbija je nacionalno veoma šarolika država. Zvanično je prepoznato 18 etničkih grupa kojima je dodeljen status nacionalnih manjina. Prema popisu iz 2002. godine, u Srbiji (bez Kosova i Metohije) živi 13,47\% pripadnika manjinskih zajednica. Najbrojniji su Mađari (293.299, tj. 3,91\%), Bošnjaci (136.087, tj. 1,81\%) i Romi (108.193, tj. 1,44\%), dok neke nacionalne manjine poput Grka broje tek nekoliko stotina pripadnika. Nacionalno najkoloritniji deo Srbije je Vojvodina. Dve glavne etničke zajednice su Mađari (14,28\%) i Srbi (65,05\%). Mađari čine većinsko stanovništvo u šest opština na severu Vojvodine, a prisutni su u još dvadeset pet drugih opština u tom delu države. Pored srpskog jezika i ćiriličnog pisma, u službenoj upotrebi u Vojvodini su još i mađarski, slovački, hrvatski, rumunski i rusinski i njihova pisma. Većina pripadnika neke manjinske zajednice skoncentrisana je u jednom delu države, izuzev Roma koji žive po celoj Srbiji.

Etničke manjine u Srbiji, bez Kosova i Metohije, prema popisu iz 2002. godine:

\begin{tabular}{|l|l|}
\hline Etnička grupa & Rezultati popisa iz 2002. godine \\
\hline Mađari & 293.299 \\
\hline Bošnjaci & 136.087 \\
\hline Romi & 108.193 \\
\hline Hrvati & 70.602 \\
\hline Albanci & 61.647 \\
\hline Slovaci & 59.021 \\
\hline Vlasi & 40.054 \\
\hline Rumuni & 34.576 \\
\hline Makedonci & 25.847 \\
\hline Bugari & 20.497 \\
\hline Bunjevci & 20.012 \\
\hline Rusini & 15.905 \\
\hline Ukrajinci & 5.354 \\
\hline Nemci & 3.901 \\
\hline Jevreji & 1.158 \\
\hline Egipćani & 814 \\
\hline Aškali & 584 \\
\hline Grci & 572 \\
\hline
\end{tabular}

Izvor: OSCE - Ethnic Minorities in Serbia, an Overview, 2008. 
Svi ovi podaci ukazuju na činjenicu da je Srbija multietnička i multikulturalna država. Republika Srbija svojim najvišim pravnim aktima garantuje, ne samo opšta ljudska prava koja stoje na raspolaganju svim njenim građanima, već i posebna prava manjina. U kategoriju posebnih prava manjina spadaju ona prava koja su manjinama kao kolektivitetima odnosno njihovim pripadnicima zajamčena kao jedna vrsta "pozitivne diskriminacije" $i$ to upravo iz razloga što se radi o stanovništvu koje se nalazi u manjinskom položaju, te je njegov status i identitet potrebno na određeni način i dodatno pravno osigurati (Krivokapić 1996: 160). Među najvažnija Ustavom utvrđena posebna prava etničkih manjina odnosno njihovih pripadnika spadaju:

- pravo na očuvanje, razvoj i izražavanje njihove etničke, kulturne, jezičke i druge posebnosti;

- izričito pravo na slobodnu upotrebu svog jezika i pisma;

- pravo na školovanje na svom jeziku;

- pravo na javno informisanje na svom jeziku;

- službenu upotrebu jezika manjina na područjima na kojima one žive;

- pravo da nastavni programi prosvetnih ustanova obuhvataju i njihovu istoriju i kulturu; i dr.

Prema Ustavu, zaštita manjina i njihovih jezika uživa u Srbiji visok stepen priznanja. Ustavom Republike Srbije iz 2006. godine i ratifikacijom dva glavna instrumenta Saveta Evrope - Okvirne konvencije za zaštitu prava i sloboda nacionalnih manjina iz 2001, i Evropske povelje o regionalnim ili manjinskim jezicima iz 2005, stvoren je pravni okvir kojim se štite ne samo individualna već i kolektivna prava nacionalnih manjina. Prema odredbama ovih dokumenata, manjinskim narodima garantuje se pravo na svoj jezik i pismo, obrazovanje i informisanje na maternjem jeziku, zaštitu kulturnog identiteta kao i na službenu upotrebu svog jezika i pisma. Pored Ustava, niz zakona i podzakonskih akata takođe reguliše pitanje prava manjinskih zajednica. Najvažniji je savezni Zakon o zaštiti prava i sloboda nacionalnih manjina iz 2002, koji je usvojen na federalnom nivou i koji je država Srbija nasledila nakon raspada Državne zajednice Srbije i Crne Gore. Njime je uređen način ostvarivanja službene upotrebe jezika i pisma (obavezna u jedinicama lokalne samouprave gde pripadnici manjina čine najmanje 15 odsto stanovništva) i izbor nacionalnih simbola i znamenja. Pored ovoga, Srbija je potpisala bilateralne sporazume sa četiri susedne zemlje: Rumunijom (2002), Mađarskom (2003), Hrvatskom (2004), i Makedonijom (2004). Kao jedno od najvećih dostignuća stručnjaci navode usvajanje zakona koji nacionalnim manjinama omogućava formiranje nacionalnih saveta preko kojih ostvaruju ova prava. Pripadnici deset nacionalnih manjina konstituisali su svoje nacionalne savete (Bunjevci, Bugari, Bošnjaci, Mađari, Romi, Rumuni, Rusini, Slovaci, Ukrajinci i Hrvati) i njihovi nacionalni saveti obaveštavaju organe, između ostalog, 0 pitanjima koja se odnose na službenu upotrebu jezika.

Obrazovanje na jezicima nacionalnih manjina uređeno je zakonima Republike Srbije o osnovama sistema obrazovanja i vaspitanja, društvenoj brizi o deci, osnovnoj, srednjoj, višoj školi i univerzitetu.

Na osnovu ovih podataka može se zaključiti da je država Srbija orijentisana ka modelu jezičke raznovrsnosti i očuvanju manjinskih jezika, budući da ne samo što 
priznaje postojanje brojnih manjinskih zajednica na svojoj teritoriji već im i brojnim pravnim sredstvima garantuje jezička prava.

\section{JEZIČKA POLITIKA I PLANIRANJE NA PRIMERU VLAŠKE MANJINSKE ZAJEDNICE U SRBIJI}

Komitet eksperata Saveta Evrope je 2009. godine sačinio izveštaj sa ciljem da ispita realnu situaciju manjinskih ili regionalnih jezika u Srbiji, i meru u kojoj Srbija primenjuje Povelju o regionalnim ili manjinskim jezicima koju je ratifikovala 2005. godine. Treba istaći da je Srbija izabrala da Povelju primenjuje samo na regionalne i manjinske jezike koji su u službenoj upotrebi prema nacionalnom zakonodavstvu. Izveštaj analizira stanje albanskog, bošnjačkog, bugarskog, bunjevačkog, hrvatskog, češkog, nemačkog, mađarskog, makedonskog, romskog, rumunskog, rusinskog, slovačkog, ukrajinskog i vlaškog jezika. Ovaj odeljak se fokusira na položaj i jezička prava vlaške manjinske zajednice u Srbiji.

U Srbiji, pod Vlasima narod podrazumeva stanovništvo severoistočne Srbije ${ }^{2}$ koje se služi jednim romanskim govorom ${ }^{3}$ i izdvaja se nekim osobenostima u folkloru, načinu života i mentalitetu (Petrović 1996: 795). Vlasi nisu kompaktni u etničkom smislu, već se dele na više grupa, među kojima su tri osnovne: Carani, Ungurjani i Munćani, a zasebnu grupu Vlaha čine Bufani. Prema poslednjem izvršenom popisu stanovništva, ova zajednica broji 40.054 pripadnika, od kojih 92\% govori vlaški kao maternij jezik, koji nije kodifikovan. U Srbiji su predstavljeni preko Nacionalnog saveta vlaške nacionalne manjine.

Sporenja o nacionalnom identitetu Vlaha godinama su prisutna među pripadnicima vlaške nacionalne manjine. Dok jedni ističu rumunsko poreklo Vlaha, drugi tvrde da su Vlasi zaseban etnički entitet. U gore pomenutom Izveštaju Komiteta eksperata navodi se da su pripadnici vlaške nacionalne zajednice podeljeni oko pitanja da li je vlaški poseban jezik ili je varijetet rumunskog. Stav Ministarstva za ljudska i manjinska prava je da „vlaški jezik nije standardizovan” i da „među pripadnicima vlaške nacionalne manjine nema saglasnosti o standardizaciji tog jezika", pa samim tim on ne može biti u službenoj upotrebi državnih organa. Međutim, Nacionalni savet vlaške nacionalne manjine koji je osnovan 2006. godine, tvrdi da je vlaški varijetet rumunskog, a ne nezavisan jezik. Savet zagovara službenu upotrebu rumunskog u opštinama s većinskim vlaškim stanovništvom, a ne standardizaciju vlaškog. Štaviše, Savet je proglasio rumunski književni jezik za maternji jezik Vlaha i preporučio njegovo uvođenje u službenu upotrebu na teritoriji gde žive pripadnici vlaške nacionalne manjine, kao i njegovo uvođenje u obrazovni sistem vlaške nacionalne zajednice u Srbiji.

Neslaganje među samim pripadnicima vlaške zajednice oko toga koji je njihov maternji jezik otežava unapređenje statusa vlaškog jezika. Prema rezultatima popisa stanovništva iz 2002. godine, na kojem su građani Republike Srbije slobodnom voljom odgovarali i na pitanja o nacionalnoj pripadnosti i o maternjem jeziku, u Srbiji živi 40.054 Vlaha i 34.576 Rumuna, a od ovog broja Vlaha 91,89\% se izjasnilo da im

2 Budući da je i AP Vojvodina deo Srbije, preciznije je reći da Vlasi žive u istočnim delovima zemlje.

3 Tačnije, govore jezikom iz romanske grupe indoevropske porodice jezika. 
je maternji jezik vlaški, 7,71\% se izjasnilo da im je maternji jezik srpski, a 0,30\% se izjasnilo da im je rumunski maternji jezik. Dakle, rezultati popisa stanovništva ukazuju na to da rumunski i vlaški nisu isti jezik i da je broj govornika ovih jezika različit. Da bi vlaški jezik mogao da bude obuhvaćen jezičkom obrazovnom politikom u Srbiji i da bi stekao status službenog jezika, neophodno je da prethodno bude standardizovan i zvanično propisan kao maternji jezik ovog kolektiviteta. Međutim, sama država ne sme se mešati u pitanje samoodređenja neke manjinske zajednice na teritoriji na kojoj ona živi, već ta zajednica mora samostalno postići saglasnost po pitanju svog etničkog porekla, maternjeg jezika i svega drugog.

Pitanje položaja Vlaha u Srbiji za sada je skoncentrisano na tri suštinska zahteva koja je njihov Nacionalni savet kao legitimno izabrani predstavnik ovog kolektiviteta zvanično postavio. Prvi je njihovo priznavanje kao nacionalne manjine rumunskog naroda koja živi u istočnoj Srbiji, drugi je pravo na obrazovanje Vlaha na rumunskom jeziku, i treći, najosetljiviji zahtev, jeste pravo na bogosluženje na rumunskom jeziku, što bi u praksi značilo formiranje eparhije Rumunske pravoslavne crkve u Timočkoj krajini, ili proširenje područja delovanja Rumunskog pravoslavnog vikarijata u Vršcu. Tome se predstavnici Srpske pravoslavne crkve izričito protive, tvrdeći da je Timočka krajina pod jurisdikcijom Srpske pravoslavne crkve, te da viševekovni crkveni kanoni jasno zabranjuju da na prostoru jedne eparhije deluju dve crkve. Dodatni problem nastao je kada je Srbija potpisala briselski Protokol o manjinama marta 2012. godine, čime se obavezala da će rešiti pitanje jezika bogosluženja, odnosno obezbediti manjinskoj zajednici u Timočkoj krajini bogosluženje na rumunskom jeziku. Predstavnici SPC tvrde da se na taj način država umešala u liturgijska pitanja, čime se zadire u uređenje SPC i međucrkvene odnose.

Po pitanju prava na javno informisanje na svom jeziku, u Izveštaju se tvrdi da je potrebno jače prisustvo vlaškog jezika na radiju i televiziji, i da je vlaški jezik nedovoljno zastupljen u kulturnim aktivnostima organizovanim u opštinama u vlaškom govornom području. Ističe se da država Srbija podržava emitovanje radijskog i TV programa na vlaškom jeziku, kao i da postoji program na vlaškom jeziku koji emituje jedan privatni radio. Što se tiče štampanih medija, jednom do dva puta godišnje štampa se brošura na vlaškom. Autori Izveštaja zaključuju da Srbija pokazuje posvećenost očuvanju vlaškog jezika, ali da treba još da radi na kreiranju i primeni jasne i strukturisane politike koja bi podsticala upotrebu vlaškog u javnom životu.

Što se tiče prava na školovanje na svom maternjem jeziku, Vlasi do sada nisu imali mogućnost da ostvare ovo pravo. U Srbiji postoje tri modela obrazovanja na regionalnom ili manjinskom jeziku u osnovnim i srednjim školama. Nastava se može odvijati na regionalnom ili manjinskom jeziku, dvojezično (sa srpskim), ili na srpskom uz mogućnost učenja regionalnog ili manjinskog jezika sa elementima nacionalne kulture što je oko 2-4 sata nedeljno. Kako se u Izveštaju navodi, vlaški jezik se ne uči ni po jednom od ovih modela, već samo u okviru nekoliko privatnih kurseva. Ističe se da vlaška zajednica nema mogućnost formalnog obrazovanja na svom maternjem jeziku i da je neophodno da država obezbedi sredstva i osmisli oblike nastave vlaškog jezika na svim nivoima u opštinama gde se on koristi.

U Komentarima koje su dale na Izveštaj Komiteta eksperata o primeni Evropske povelje o regionalnim ili manjinskim jezicima u Srbiji, vlasti u Srbiji se ograđuju od bilo kakvog nametanja nacionalnog identiteta i maternjeg jezika ovoj, i bilo kojoj drugoj 
manjinskoj zajednici. Dalje, navodi se da ne postoje smetnje u okviru državne zakonske regulative za učenje bilo rumunskog ili vlaškog jezika. Međutim, neophodno je da se Nacionalni savet vlaške manjinske zajednice izjasni o tome na kom će jeziku pohađati nastavu njihova deca i da podnese zvaničan zahtev Ministarstvu prosvete. Naime, 2005. godine Ministarstvo prosvete je predložilo vlaškom Nacionalnom savetu da pokrene inicijativu za uvođenje vlaškog jezika u školama u vlaškom govornom području, ali prema rečima nadležnih u Ministarstvu prosvete, vlaška zajednica nije uputila nikakav zvanični zahtev po ovom pitanju.

U skladu sa državnom zakonskom regulativom, vlaška zajednica može da se opredeli za sledeće: a) mogu da imaju celokupnu nastavu na rumunskom jeziku za šta nastavni planovi i programi već postoje, b) mogu da imaju celokupnu nastavu na rumunskom jeziku uz mogućnost izbora izbornog nastavnog predmeta Vlaški jezik sa elementima nacionalne kulture i, c) mogu da pohađaju celokupnu nastavu na srpskom jeziku uz mogućnost izbora nastavnog predmeta Vlaški jezik sa elementima nacionalne kulture ili Rumunski jezik sa elementima nacionalne kulture. Jedino nemaju mogućnost pohađanja celokupne nastave na vlaškom jeziku budući da on nije standardizovan i da u Srbiji ne postoji visokoškolska ustanova na kojoj bi predavači koji bi izvodili nastavu na vlaškom jeziku stekli formalno obrazovanje. Međutim, ukoliko bi Nacionalni savet uputio Ministarstvu prosvete zvanični zahtev za izvođenje nastave na vlaškom jeziku, najpre bi morao biti izrađen nastavni plan i program za ovaj predmet, nakon čega bi bilo moguće organizovati nastavu u školama koja pohađaju deca ove manjinske zajednice.

Iako je $s$ jedne strane dobro što se država ne meša u unutrašnje pitanje samoodređenja vlaške zajednice, neophodno je da se pronađu i ojačaju mehanizmi koji bi pomogli očuvanju i razvoju njihove etničke, kulturne i jezičke posebnosti. Neophodna je pre svega standardizacija vlaškog jezika da bi se mogao naći u službenoj upotrebi, i da bi mogao biti uključen u jezičku obrazovnu politiku i planiranje. Ustavom i drugim zakonima ovoj, kao i drugim nacionalnim manjinama, pravo na školovanje na maternjem jeziku jeste zagarantovano, ali je potrebno da vlaški jezik bude zvanično priznat od strane Nacionalnog saveta ove etničke zajednice kao njihov maternji jezik da bi Vlasi mogli da ostvare ovo pravo. Uprkos ovim preprekama usled kojih pripadnici ove manjinske zajednice ne mogu da se školuju na vlaškom jeziku, ono što država može da uradi jeste promovisanje vlaškog jezika u javnoj i medijskoj sferi, širenje tolerancije i podizanje svesti o značaju multikulturalnosti i višejezičnosti.

\section{ZAKLJUČAK}

Održavanje i revitalizacija jezika su u tesnoj vezi sa podizanjem svesti populacije o gorućem problemu izumiranja jezika, obezbeđivanjem resursa za obrazovanje i opismenjavanje ljudi na etničkom jeziku, kao i sa političkim angažovanjem i institucionalnom podrškom koja je neophodna da bi se manjinski jezici dugoročno održali. Neophodno je priznavanje pozitivnih jezičkih prava manjinskim zajednicama na svoj jezik i pismo, obrazovanje i informisanje na maternjem jeziku, zaštitu kulturnog identiteta i službenu upotrebu njihovog jezika i pisma. Obrazovna jezička prava najvažnija su za održanje i razvoj jezika, odnosno za globalni jezički i kulturni 
diverzitet. Sve je veći broj povelja, deklaracija i konvencija koji jezička prava ubrajaju u fundamentalna ljudska prava. Odgovarajuća jezička politika i obrazovanje mogu podstaći vitalnost, raznovrsnost i stabilnost ugroženih i manjinskih jezika, a konačno i prava njihovih govornika da ravnopravno učestvuju u globalnom društvu.

\section{LITERATURA}

Bugarski, R. 1996. Jezici. Novi Sad: Matica Srpska.

Council of Europe. 2009. European Charter for Regional or Minority Languages. Application of the Charter in Serbia. [Internet]. Dostupno na: http://www.unhcr. org/refworld/country ${ }_{11}$ COEMINISTERS,,SRB ${ }_{11}$ 4a029b670,0.html [24.11.2012].

Christensen, G. \& P. Stanat. 2007. Language policies and practices for helping immigrants and second-generation students succeed. [Internet]. Dostupno na: http://www. migrationpolicy.org/pubs/christenseneducation091907.pdf [19.11.2012].

Edwards, J. 2001. Language and Language Learning in the Face of World English. Profession (Annual of the Modern Language Association), 109-120.

Eriksen, T.H. 1992. Linguistic Hegemony and Minority Resistance. Journal of Peace Research 29(3), 313-332.

Filipović, J. 2009. Moć reči. Beograd: Zadužbina Andrejević.

Harper, S.M. 2011. Counting the Costs of a Global Anglophonic Hegemony: Examining the Impact of U.S. Language Education Policy on Linguistic Minorities WorldWide. Indiana Journal of Global Legal Studies 18 (1), 515-538.

Hinton, L. 2003. Language Revitalization. Annual Review of Applied Linguistics 23, 44-57.

Hornberger, H.N. 1998. Language policy, language education, language rights: indigenous, immigrant, and international perspectives. Language in Society 27, 439-458.

Krivokapić, B. 1996. Neki problemi u vezi sa pravnom uređenošću položaja manjina u SR Jugoslaviji. U V. Stanojčić (ur.) Položaj manjina u Saveznoj Republici Jugoslaviji. Beograd: SANU, 155-169.

Kymlicka, W. \& A. Patten. 2003. Language Rights and Political Theory. Annual Review of Applied Linguistics 23, 3-21.

OSCE. 2008. Ethnic Minorities in Serbia, an Overview. [Internet]. Dostupno na: http:// www.osce.org/serbia/3098 [14.11.2012].

Petrović, D.S. 1996. Vlasi Severoistočne Srbije kao etnički entitet. U V. Stanojčić (ur.) Položaj manjina u Saveznoj Republici Jugoslaviji. Beograd: SANU, 795-814.

Phillipson, R. \& T. Skutnabb-Kangas. 1997. Linguistic human rights and English in Europe. World Englishes 16(1), 27-43.

Skutnabb-Kangas, T. \& R. Phillipson. 1996. Minority Workers or Minority Human Beings? A European Dilemma. International Review of Education 42(4), 291-307.

Skutnabb-Kangas, T. 1998. Human Rights and Language Wrongs - a Future for Diversity? Language Sciences 20(1), 5-27.

Zakon o zaštiti prava i sloboda nacionalnih manjina, Službeni list SRJ, br. 11/2002. [Internet]. Dostupno na: http://www.ljudskaprava.gov.rs/images/propisi/zakon_o_ zastiti_sloboda_i_prava_nacionalnih_manjina.pdf [13.12.2012]. 


\section{SUMMARY}

\section{MINORITY LANGUAGE MAINTENANCE AND LANGUAGE POLICY: THE CASE OF THE VLACH MINORITY IN SERBIA}

The issue of the protection of minority languages has been a widely-discussed topic in scientific and political circles for several decades. The paper advocates bilingual education as a means for preserving minority languages and language diversity in states with a dominant monolingual ideology. Immigrants to Western countries pass on their mother tongue to their children, but they rarely pass it on further, so the language is lost by the third generation. This calls for strong state language policies that would prevent language loss. The second part of the paper deals with the legal regulation of the status of minority languages in Serbia with a particular focus on the Vlach minority language.

KEYWORDS: language policy, minority language, immigrants, Serbia, the Vlach minority.

(Originalan naučni rad primljen 18.12.2012;

ispravljen 02.09.2013;

prihvaćen 17.12.2013) 